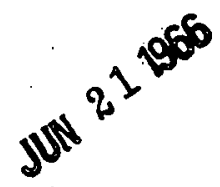

DEPARTMENT OF COMPUTER SCIENCE

UNIVERSITY OF ILLINOIS

URBANA, ILLINOIS

RELEASED FOR ANNOUNCERENT

IN NUCIEAR SCIENCE ABSTRACTS

\section{LEGAL NOT:ICE}

This report was prepared as an account of Government sponsored work. Nelther the United States, nor the Commission, nor any person acting on behalf of the Commission:

A. Makes any warranty or representation, expressed or Implled, with respect to the accuracy, completeness, or usefulness of the information contained in this report or that the use of any information, apparatus, method, or process discloged in this report may not infing privately owned rights; or

B. Assumes any liabluttes with respect to the use of or for damageo resulting from the

of any information, apparatus, method, or process disclosed in this report.

As used in the "ave. "pert ployee or contractor of the comming ployec or extent that dise disseminates, or provides access to, any information pursuant to his employment or contract with the Commission, or his employment with such contractor.

\title{
DESCRIPTION AND ANALYSIS OF THE IBM 2741
}

\author{
by
}

Edwin B. Hassler

File No. 687 


\section{DISCLAIMER}

This report was prepared as an account of work sponsored by an agency of the United States Government. Neither the United States Government nor any agency Thereof, nor any of their employees, makes any warranty, express or implied, or assumes any legal liability or responsibility for the accuracy, completeness, or usefulness of any information, apparatus, product, or process disclosed, or represents that its use would not infringe privately owned rights. Reference herein to any specific commercial product, process, or service by trade name, trademark, manufacturer, or otherwise does not necessarily constitute or imply its endorsement, recommendation, or favoring by the United States Government or any agency thereof. The views and opinions of authors expressed herein do not necessarily state or reflect those of the United States Government or any agency thereof. 


\section{DISCLAIMER}

Portions of this document may be illegible in electronic image products. Images are produced from the best available original document. 
The IBM 2740 and 2741 are IBM's versions of a printer-keyboard designed primarily for point to point communication. The 2740 is the more glorious one with numerous options. The 274l is as simple as possible with just one major option. Neither of these units approaches the complexity or number of options available on a 1050 system.

A prototype IBM 2741 was in house from about December 1, 1965; through January 10; 1966. During this time its operation was investigated using the PDP $7-630$.

Physically, the prototype 2741 was a 1051. (the 1050 electronics box) modified and attached to a selectric. The real. $2741 \mathrm{~s}$ will be a table mount affair about the same size and shape as the prototype table with the selectric mounted in the top and the electronics mounted in a skirt on the back of the table.

There are only two operating controls, the power switch on the typewriter and the power switch on the electronics which will be labeled remote and local. That is, in local (or electronics off) you have a normal selectric. Remote ties you to the phone line.

It uses a selectric which means you have all the problems of a selectric-re, our console selectrics:- The rumor persists (ask any IBM type) that something special is about to be done to selectrics used for I/O devices. It appears that they are aware of the problems, but real solutions have yet to be seen. The prototype 2741 had a selectric identical to ours.

Selectric difficulties noted during our test.

1) Keyboard lock on the space bar and shift is too fragile. It can be easily bent by forgetting about it and trying to type.

2) Repeated mechanical functions in series slow the mechanism down. Therefore, say a series of repeated up and down shifts: takes place. You will slow the mechanism down, the mechanical timing pulses to the electronics will be late and it will begin to miss characters.

Use-wise it is easy to use. Three specific points should be noted.

1) Two special characters are used. One is transmitted to the computer by the 2741 to indicate end of message. The user 
sends it by typing the LF/LR key. This also locks his keyboard. The second character unlocks the user's keyboard.. It is a shame IBM persists in this controlled half-duplex mode. A user directed half-duplex would be nicer, i.e., teletype style.

2). The character set.is the selectric code complete with shift characters, similar to the console typewriters but not quite the same in the nonstandard characters. Checking is by single bit parity (odd).

3) The idle character nonsense for some mechanical functions remains. Engineering-wise - a.few headaches. The 1050 operates at 15 characters per second maximum rate. They do this on input by locking the keyboard between each character you type. That is what makes the 1050 keyboard feel as though you are typing on an old stiff mechanical. The mechanical timing of the selectric is such that it. likes to run a 16.5 characters per second. The 2741 runs at full selectric speed.

\section{"This means".}

1) The keyboard has a decent feeling again.

2) The character time is shortened from $67 \mathrm{~ms} /$ characters to 60.7 ms/character.

(Internal clock speeds $134.49 \mathrm{bits} / \mathrm{sec}$. to $149.3 \mathrm{bits} / \mathrm{sec}$.)

We operated by reducing the clock speed to the 1050 value. This meant that you could type faster than the characters were transmitted and consequently either. lose characters or get garbage characters. Normal use of a 2741 . would require changing the 630 clock frequency.

\section{Use and Ordering}

Nothing could be simpler. You specify either $103 \mathrm{~A}$ or a 1,2 , or 4 line multiplex $M \phi D E M$ interface. (Changeable by card plugging in the field.) Some options as to platen (pin-feed mainly). The only major option is the attention feature. Thịs requires a duplex data line and has the same effect as the teletype break. A must if we are to use.274ls. 
Problems - Summarized .

The selectric; once bitten, twice shy. IBM would have to demonstrate that they have licked the problems in that thing. The code; typewriter and with shift characters. It. would be nice if the code were closer to what we use, even better if it were ASCII. Maybe this could happen.

\section{$\underline{\text { Recommendations }}$}

The 2741 provides a large character set with upper and lower case plus a wide carriage.

With the selectric made reliable and ASCII code the 2741 could be used as a direct substitute for Model. 37. teletype with the advantage of the wide carriage.

With the ASCII code or the selectric made reliable, it is a poor substitute for the Model 37 teletype (current field date for Model 37 is now +9 months).

If the selectric is not fixed and the code not changed, a temporary substitute for the Model 37 only:

Cost

\begin{tabular}{|c|c|c|c|}
\hline & Base Price & $\begin{array}{l}\text { Data Set } \\
\text { Connection }\end{array}$ & $\begin{array}{l}\text { Attention } \\
\text { Feature }\end{array}$ \\
\hline $\begin{array}{l}\text { Rental } \\
\text { Purchase }\end{array}$ & $\begin{array}{l}\$ 80 / \text { month } \\
\$ 3,200\end{array}$ & $\because \underset{\$ 3}{\$ 135}$. & $\begin{array}{l}\$: 2.50 / \text { month } \\
\$ 115.00\end{array}$ \\
\hline
\end{tabular}

